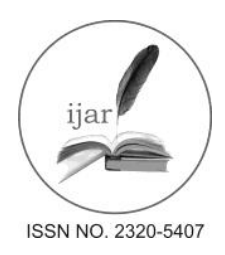

Journal homepage:http://www.journalijar.com

Journal DOI:10.21474/IJAR01

\section{RESEARCH ARTICLE}

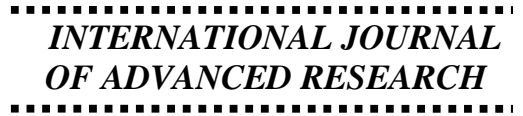

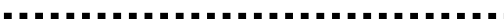

\title{
MYANMAR'S CHANGING FOREIGN RELATIONS AND INDIA.
}

Vanlalpari.

Research Scholar, Centre for Canadian, United States \& Latin American Studies (CCUS\&LAS), School of International Studies, Jawaharlal Nehru University, New Delhi - 110067, India.

\section{Manuscript Info}

Manuscript History:

Received: 18 April 2016

Final Accepted: 19 May 2016

Published Online: June 2016

Key words:

Myanmar's transition; foreign

policy; India.

*Corresponding Author

Vanlalpari.

\section{Abstract}

With Myanmar's transition to a democracy opening the door for Western governments to rebuild their relations with Myanmar, the country now has more space to maneuver its policy conduct to further enhance its reform movements by engaging with more players. In this new environment, this paper focused on the previous relations that Myanmar maintained before its transition in whichthe relation with India had been singled out. The paper had examined the bilateral relationship from past to present as well as the evolution of Myanmar's foreign policy through the years and assessed how Myanmar reoriented its foreign affairs after the transition enhanced the country's reform and development process and how the relation with India had been taken forward in this new political set-up.

Copy Right, IJAR, 2016, All rights reserved.

\section{Introduction:-}

Myanmar's bilateral relations as well as the broader foreign policy undertakings have undergone alterations since the country embarked on its democratic transition beginning 2011. Ever since reform process began on the country's political, economic and social conditions, interest on the country escalated from both the long-time friendly countries and the previously hostile ones. Western governments, which for more than two decades opted to punish the military regime (the State Law and Order Restoration Council/SLORC later transformed as the State Peace and Development Council/SPDC), by economic sanction and isolation, have enthusiastically welcomed these changes. Policies to improve ties with Myanmar have been intently pursued with most of these governments completely dropping the sanctions policy while some like the US opting on easing it in a timely manner. In such an environment, undoubtedly, these new changes have affected Myanmar's relation with those it has maintained ties throughout the sanction and isolation era(Singh 2014: 11).

The aim of the paper is therefore to assess how Myanmar situates the already established relations maintained before the country's transition in itscurrent evolving foreign policy conduct which has been adjusting to the changes brought about by the democratic transition. The bilateral relation with India has been singled out for analysis in this paper. Since there is already a plethora of studies on the two countries relation especially from the Indian perspective, the paper's focus has thus been on how Myanmar has taken forward its relation with India in this new phase where competition in the country has increased with the entry of Western governments. The discussion of the bilateral relation through the years has been undertaken under two sub-themes divided as: a) 'Pre-Transition Relation' which has included a brief overview of the two countries relation since ancient times up to the SLORC/SPDC rule in Myanmar; and b) 'Post-Transition Relation' which talks about the relation since anew civilian government took over in 2011. Then a brief highlight on the history of Myanmar's foreign policy has been made and finally concluded with the discussion on how Myanmar is adjusting its foreign policy conduct and its relation with India since its transition. 


\section{Pre-Transition Relation:-}

Myanmar's relation with India began when India's influence started to expand eastward through the sea-faring adventures undertaken towards the east (Ghosh 2016: 150). However, it was the British colonization of Myanmar that broadened the relation even though cultural and economic exchanges began as early as the $3^{\text {rd }}$ century BC (Egreteau 2003: 7-13). Myanmar was annexed as a part of British-India and governed under the Indian sub-continent (Myint-U 2011: 18). The growth of trade and commerce under the British led to huge migration of Indians to the country, both educated and uneducated, to work mostly as civil servants; clerks; merchants and coolies and very soon outnumbered the local population, oftenholding better positions than them (Steinberg 1982: 37-41; Egreteau 2003: 15; Myint-U 2011: 19). This domination by another class apart from the British was deeply resented by the local people and eventually resulted in riots against Indians during 1930-1931 and again in 1938 compelling many Indians to leave the country (Steinberg 1982: 40-41; Egreteau 2003: 15, 20).

It was only after both the countries gained independence from the British(India in 1947 and Myanmar in 1948) that proper diplomatic relation was established between them. During the colonial rule itself, the growth of nationalist movements in India had influenced the Burmese and the post-independence democratic government under U Nu's leadershipopted for non-alignment in foreign policy along with India and other newly independent nations of former colonies in Asia, Africa and Latin America and good relations was thus forged with India (Egreteau 2003: 17-18, 30-31). Visits by dignitaries of both countries were undertaken frequently during this period and the "Treaty of Perpetual Peace and Friendship" was signed on 7 July 1951 to further cement their relationship (Egreteau 2003: 31). A close friendship was thereby enjoyed by Myanmar and India (Sein 2014: 70).

The situation however changed from 1962 with the establishment of the military regime in Myanmar under General $\mathrm{Ne}$ Win and because of the socialist and the nationalization policies, Indians became bereft of their positions in the country forcing many to leave (Egreteau 2003: 33-35). Despite this situation in Myanmar, state visits were still encouraged by both leaders even though India had made it clear that it did not support the military government (Egreteau 2003: 35-36). In fact, both governments tried to rekindle relations through the promotion of nonalignment and 'mutual understanding' (Sein 2014: 71). During this time, insurgent groups fighting for independence were on the rise in India's northeast and thus, engaging Myanmar was essential for India. With common borders and Myanmar experiencing similar situation of struggle for independence from its ethnic groups who share racial kinship with those in the northeast of India, insurgency became a problem both countries needed to address (Egreteau 2003: 57-66; Trivedi 2014: 86-87). Relation was thus carried on though it was neither friendly nor hostile.

This casual relation was, however, further diminished by the early 1990s incidents in Myanmar. In the 1988 incident where peaceful protestors were brutally suppressed by the military, India opened its embassy in Myanmar as refuge for protestors and welcomed the civilians fleeing the military to India (Egreteau 2003: 121-129; Myint-U 2011: 268; Trivedi 2014: 79). Later, when the military refused to accept the 1990 election result which was won by Aung San Suu Kyi's National League for Democracy (NLD), India strongly stated that the military should respect the result and let the NLD form the government (Myint-U 2011: 268; Sein 2014: 71). Therefore, during the early 1990s, India was sympathizing the movement for democracy in the country and even bestowed the 'Jawaharlal Nehru Award for International Understanding’ to Suu Kyi in 1993 (Myint-U 2011: 270; Trivedi 2014: 79).

With India taking this position and the West with the sanctions and isolation policy, China was presented with a great opportunity to improve its relation with Myanmar. China successfully enhanced its influence, especially on the defense partnership, alarming other countries including India, and resulted inIndia's reorientation of the initial policy rooted in the ideological principle of democracy to a more pragmatic one - the 'Look East Policy' - which was initiated in 1993 by the Narasimha Rao government focussingnot just on Myanmar but the whole of Southeast Asia (Ergreteau 2003: 132-133; Haacke 2006: 34; Myint-U 2011: 268-269; Ranjan 2014: 42; Trivedi 2014: 79-80). The military regime of Myanmar also eventually realized the need to balance China's growing influence in the country and thus, building ties with India both in the political and economic realms became imperative in order to lessen dependence on China's assistance (Haacke 2006: 38).

Apart from the concern for China, India's interest in Myanmar is largely influenced by the geo-strategic location of the country. Myanmar is the gateway for India's landlocked northeast region which could be developed tremendously by connecting with Southeast Asia (Myint-U 2011: 306; Ranjan 2014: 42). The 'Look East Policy' was thus formulated to encompass India's interest on both the strategic and economic front (Haacke 2006: 34). The 
India-Myanmar friendship road project is one amongst the many that was initiated and financed by India so that land connectivity could be used for India's developmental purposes (Htun et al. 2011 in Ghosh 2016: 163; Egreteau 2003: 144). Roads connecting the two regions such as the Stillwell Road constituting both the Ledo Road and the Burma Road which have been maintained since colonial times got upgraded to enhance trade and transport facility (Egreteau 2003: 170-173; Ghosh 2016: 158-159).

Issue of tackling insurgency also improved during the SLORC/SPDC period. Important changes have happened since the early 1990s situation where accusations against each other of supporting insurgents not belonging to their respective country and violation of each other's territories due to separate counter-insurgency operations were common (Egreteau 2003: 129-131). It was because of the thaw in the bilateral relations that in 1995 a joint operation against insurgency, the "Operation Gold Bird," could be undertaken (Myint-U 2011: 270; Trivedi 2014: 87). Problem of illegal sale of arms amongst rebels as well as drug trafficking also resulted in cooperation of the two countries including the issues of HIV/AIDS which has risen to alarming rates in the border areas (Egreteau 2003: 66-72; Trivedi 2014: 85-86).

Since the mid-1990s, both countries have been involved at the sub-regional level initiatives such as BIMSTEC (Bay of Bengal Initiative for Multi-Sectoral, Technical and Economic Cooperation/Bangladesh-India-Myanmar-Sri Lanka-Thailand Economic Cooperation), BCIM (Bangladesh-China-India-Myanmar Forum/the Kunming Initiative) and the MGC (Mekong Ganga Cooperation) apart from the bigger regional cooperation such as the ASEAN, the ASEAN Regional Forum (ARF) and others (Egreteau 2003: 103, 104, 109, 111; Haacke 2006: 35; Trivedi 2014: 82). Military cooperation which provides training for Burmese officers at defense academy in India; exchange of visits from military officers of both the countries; participation of Myanmar in the MILAN naval exercises organized by India for confidence building amongst the navies of the Indian Ocean region; and the resumption of sale of military equipment to Myanmar are a few major military cooperation between the two countries in the past decades (Egreteau 2003: 136, 139-143, 164-166; Haacke 2006: 36-37).

India also became the fifth largest trading partner as well as the third largest export market for Myanmar (Haacke 2006: 35). Big projects like the Kaladan Multi-Modal Project since 2008 for advancing economic trade through Northeast India; trilateral highway linking India, Myanmar and Thailand since 2002; air and rail connectivity and other important projects have been undertaken (Pulipaka 2014: 122-124; Yhome 2014: 140-150). Exploitations of Myanmar's hydrocarbons and energy resources have also been pursued by India though at a much slower pace than China (Egreteau 2003: 163-164; Haacke 2006: 36). India also continued the promotion of democracy but through a different approach unlike the early 1990s. India offered the development of constitutional and democratic institutions to the military government though the gesture was considered as an attempt to heed US call to be more strict towards the militaryregime (Haacke 2006: 37). The enhanced relation with India had been helpful for Myanmar in improving its image in the international community and India's support in forums such as the United Nations Commission on Human Rights had been valuable for Myanmar's military regime (Haacke 2006: 37).

\section{Post-Transition Relation:-}

India's complicated bureaucratic system with routine delays in the execution of policies which has constrained the relation from going forward at a much faster pace can be seen as changing ever since Myanmar's transition enabled the revival of relations with the West and India has become more driven in its Myanmar policy (Trivedi 2014: 9697). The May 2012 visit of India's then Prime Minister, Manmohan Singh, to the country was an important step signaling this (Yhome 2014: 135; Trivedi 2014; 93). The previous year in 2011, Myanmar's President Thein Sein also made a visit to India and since then, frequent exchange of visits from officials of both countries have taken place and important Memorandum of Understandings (MoUs) have been signed for cementing the two countries cooperation on various projects (Ministry of External Affairs, India; Trivedi 2014: 93-94; Sein 2014: 73-74). India has since moved forward with the infrastructural projects that have already been undertaken since the SLORC/SPDC era especially on the exploitation of Myanmar's natural resources; defense and maritime security links; trade and commerce undertakings; better connectivity through land, sea and air; curbing insurgency, illegal trade which includes arms and drugs smuggling; cultural cooperation and others (Lee 2014: 300-304). A good demonstration of the improving ties has been the opening of the Border Liaison Offices since 2012 for greater cooperation towards curbing crimes and illegal trade on arms and drugs as well as to speed up sharing of secret information (Lee 2014: 300). 
These forward policies have been given a stronger push since 2014 by the newly electedModi government. The 'Look East Policy' duly renamed the 'Act East Policy' to indicate India's renewed interests on its eastern neighbors, of which relation with Myanmar remains central, was aptly announced at the $12^{\text {th }}$ India-ASEAN Summit held in November 2014 in Myanmar (Yhome 2016: 77). Even after the completion oftwo years, the Modi government has continued to emphasize on its policy of 'greater cooperation and better ties' with neighboring countries displaying the eagerness of India in not just collaborating on certain issues but also 'integration' with neighboring countries with 'renewed focus on geo-economics in the region' (Passi and Bhatnagar 2016: 3; 5). The Modi government indicated early on that deepening ties with neighboring countries will be prioritized by India and even invited leaders of these countries to his inauguration and undertook his first official trip to these countries (Yhome 2016: 78).

As Myanmar remains central in the plan to accelerate India's economic growth through the Act East Policy which includes regional connectivity through Northeast India; trade and commerce;as well as cultural connectivity and friendship between people to people, the Modi government has further pushed the infrastructural development projects already underway (Hussain 2016; Yhome 2016: 78). The most recent news relating to connectivity issues is the Motor Vehicle Agreement Act, concerning the trilateral highway project to link India with Thailand through Myanmar,which has been scheduled to be signed at the earliest by the involved parties according to India's Ministry of Road, Transport and Highway after being postponed due to Myanmar's election last year (Sharma 2016). Growing political and defense exchanges of both countries as well asaccelerating economic cooperation are definitely indicating the deepening Indo-Myanmar ties these recent years (Yhome 2016: 76). The cooperation on border security issues as well as defense partnership have also been increasing especially after the 2015 Indian Army raid on the ethnic rebel group, the United Liberation Front of Western Southeast Asia, crossing into Myanmar though the entry was initially denied by Myanmar(Yhome 2016: 79; Long and Lone 2015).

\section{Myanmar's Foreign Policy Transition:-}

For Myanmar, engaging with other countries to have wider space for maneuvering its political conduct is not a new phenomenon. Even during the 1990s when China's influence was growing in the country unmatched by none, Myanmar had already taken measures to limit this as best as the country could manage. This was done through attaining membership in the Association of Southeast Asian Nations (ASEAN) plus other regional and sub-regional organizations and improving bilateral ties with other Asian countries like India and altering its domestic policies (Haacke 2006: 21). These moves also indicated Myanmar's aspiration of being accepted by the international community (Haacke 2006: 21). Myanmar's over-dependence on China had been unavoidable due to the constraints by Western sanctions and isolation as well asthe initial hesitation to engage the military government by some Asian countries.Despite the dependence on China, Myanmar's conduct of its foreign policy has always been independent and neutral to the best of its ability.

The neutral foreign policy has been pursued by Myanmar since 1948 with the first democratic government under the leadership of U Nu and the succeeding military regime, the Burma Socialist Programme Party (BSPP) under General $\mathrm{Ne}$ Win in the 1970s, vigorously pursuing an 'independent and active' foreign policy with the last military regime, the SLORC/SPDC, continuing this tradition of remaining 'independent' in its foreign policy conduct while maintaining friendly relations with other countries (Haacke 2006: 15; Zhu 2015: 69-72). The military government had time and again demonstrated that any endeavortowards the domination of the country by any outside power will not be entertained (Haacke 2006: 19). The Sino-Myanmar relation has many times been observed as an exception to this but Myanmar's conduct has demonstrated that the country indeed maintains some level of independence even from its closest ally. One clear indicator of this had been thesudden resettling of the capital from Yangon to Naypidaw in 2005, which shocked even China, anddetermined that whatever confidence China must have had of Myanmar's military as a willing and faithful partner was not as solid as might have been perceived and clearly exhibited the resentment of the military rulers in being identified as China's 'client state' (Myint-U 2011: 50).

Therefore, it alwayshas been Myanmar's strategy to maintain balanced relation with important partners and hence the continued attempt to be 'equidistant' with its neighboring countries (Bunte and Dosch 2015: 12). After taking over from the military government on 30 March 2011, President Thein Sein said that Myanmar would continue with an independent, non-aligned and progressive foreign policy while engaging other countries to promote nationbuilding (Global Security; Pedersen 2014: 56-57; Myoe 2016: 127-128). This clearly indicated the ambition of the new government to enhance the country's development through engagement with different players while preserving the policy of maintaining its independence. Even in the newly drawn 2008 Constitution of Myanmar, an 
'independent, non-aligned and active' foreign policy striving for peace and good relations with other countries while adhering to the principles of 'peaceful co-existence' has been enshrined in Article 41 (Ministry of Foreign Affairs, Government of the Union of Myanmar; Pedersen 2014: 56; Myoe 2016: 127).

Following these principles, Myanmar has thus taken forward the country's reform movements and developmental programs. It had been essential that the new government formulate a foreign policy which could address both the external and internal pressures that were surrounding Myanmar (Zhu 2015: 74). According to Morgan Pedersen, Senior Lecturer in International and Political Studies at the University of New South Wales (Canberra, Australia) and the Australian Defence Force Academy, for enhancing the political and economic transition, Myanmar vigorously worked towards these goals: i) 'normalizing international relations' with international and regional organizations, financial institutions and western governments by exhibiting its impressive domestic reforms; ii) 'balancing major powers' due to the enhanced interest on the country from both Asian powers and the West; iii) 'promoting regional integration' by working on consolidating its relation with the ASEAN and giving efforts to situate itself as the connecting link for East, South and Southeast Asia; and iv) 'mobilizing and managing international resources' comprising all new offers of 'capital as well as advice, training and technology' which have been pouring into the country (Pedersen 2014: 64-71).

What is clear from these undertakings is that as much as courting new countries notably the West and international organizations are important in boosting Myanmar's transition process, improving the already established relations especially those with the Asian neighbors as well as regional and sub-regional organizations also play a strategic role for Myanmar and that the country has also been working on improving these relations as well. Since the importance of Asian neighbors will not diminish for Myanmar even in this new political era as they will remain the main partners of the country in trade and investment (Verbruggen 2016), Myanmar working to further strengthenthe ties with countries that it already established good relations with is both crucial and timely for the country.

With the National League for Democracy (NLD) coming to power from 2016, Myanmar's transformation to a democracy is likely to be more concrete though limiting factors do remain. Even though it is still too early to determine the path the new government will undertake, it is most likely that the previous government's policy of building good relations with every players in the country will be carried forward. Gregory Poling of the Centre for Strategic and International Studies (Washington D.C., USA) has been quoted by the Myanmar Times voicing that the policy of balancing players will continue in Myanmar (under the NDL) but instead of 'East-West' balancing, it would be against the numerous countries engaging Myanmar (Verbruggen 2016). The transition has enabled more international assistance, trade and investment to pour into the country, forwarding the reform process and enhancing Myanmar's position in the region to evolve as a contemporary 'balancer' in the region's 'new great game' (Pedersen 2014: 72; Denmark 2014: 76). How much advantage Myanmar can reap from this new found status lies on the extent of Myanmar's success in maneuvering its interests within this set-up.

\section{Conclusion:-}

In the past, Myanmar's military regime had successfully capitalized the country's strategic geographical position as well as its rich natural reserves to build better economic, political and security relations with neighboring countries though the country was limited from engaging the West by the sanctions and isolation policy (Haacke 2006: 22-23). Now that the domestic political structure has been altered by the country's transition, interest in Myanmar's location and its resources has grown with Western governments wasting no time to rebuild relation with the country. In such a situation, the general foreign policy conduct has no doubt experienced a shift as well (Singh 2014: 11). Since trade and investments plus security partnership now involves more players, Myanmar is in a position to strongly pursue its neutral and independent yet active foreign policy as the need to depend on limited countries is now diminishing.

How then has relation with India been managed in this new political situation? Ever since the transition, there has been enthusiastic response from the Indian side, as the previous discussion clearly stated, which shows India's resolve to further strengthen ties with Myanmar. In the past, Myanmar's policy interest in constructing deeper relation with India has been driven by the country's aspiration of enhancing its 'economic development, security and political support' (Haacke 2006: 35). Hence, by engaging India, Myanmar hadattempted to augment its 'economic development,' 'regional connectivity' and its foreign policy conduct so that China's role in the country might be reduced and is also consistent to India's own strategic interest in Myanmar (Denmark 2014: 82). Hence, the two countries have been improving their relation through increased cooperation on economic, political and security issues in all these years. The sanctions and isolation policy made engagement with others countries prudent for 
Myanmar so that some level of independence could be maintained despite the necessity to depend on China's aid and assistance.As such, India's role had been important and highly appreciated by the military regime. Therefore, even in this new era of Myanmar's 'great game' politics, India will continue to remain important for Myanmar. India's new thrust in trying to deepen relation with the country must be responded accordingly as this will further enhance Myanmar's capacity to balance more effectively the growing interests on the country and enable Myanmar to further strengthen its own neutral, independent and active foreign policy. India, as a major power in the region, will remain a significant force for the countrywhen managing power relations within it and hence, important for Myanmar to deepen its ties with India.

\section{References:-}

1. Bunte, Marco and Dosch, Jorn (2015): Myanmar: Political Reforms and the Recalibration of External Relations. Journal of Current Southeast Asian Affairs, 34 (2): 3-19. URL: http://journals.sub.unihamburg.de/giga/jsaa/article/view/871/878

2. Denmark, Abraham M. (2014): Myanmar and Asia's New Great Game. In: NBR Special Report \#45, Myanmar's Growing Regional Role, The National Bureau of Asian Research. Seattle, Washington: The National Bureau of Asian Research.

3. Egreteau, Renaud (2003): Wooing the Generals: India's New Burma Policy. New Delhi: Authors Press.

4. Ghosh, Lipi (2016): India-Myanmar Relations: Historical Links to Contemporary Convergences. New Delhi: Paragon International Publishers.

5. Global Security, "Myanmar - $\quad$ Foreign Relations," http://www.globalsecurity.org/military/world/myanmar/forrel.htm

6. Haacke, Jurgen (2006): Myanmar's Foreign Policy: Domestic Influences and International Implications, Adelphi Paper 381. London: The International Institute of Strategic Studies.

7. Htun, K.W. et al. (2011): ASEAN-India Connectivity: A Myanmar Perspective. In Kimura, F. and Umezaki, S. (eds.) ASEAN-India Connectivity: The Comprehensive Asia Development Plan, Phase II, ERIA Research Project Report 2010-7, Jakarta: ERIA. In Ghosh, Lipi (2016): India-Myanmar Relations: Historical Links to Contemporary Convergences. New Delhi: Paragon International Publishers.

8. Hussain, Wasbir (2016): Myanmar: A Test for Modi’s Act East Policy. The Asian Age, 29 March 2016, URL: http://www.asianage.com/india/myanmar-test-modi-s-act-east-policy-164

9. Lee, Lavina (2014): Myanmar's Transition to Democracy: New Opportunities or Obstacles for India. Contemporary Southeast Asia: A Journal of International and Strategic Affairs, 36 (2): 290-316. URL: DOI: 10.1353/csa.2014.0015

10. Long, Kayleigh and Lone, Wa (2015): Governement Denies India Operation Took Place in Myanmar. Myanmar Times, 11 June 2015. URL: http://www.mmtimes.com/index.php/national-news/14978-government-deniesindia-operation-took-place-inside-myanmar.html

11. Ministry of External Affairs, Government of India: India's Relation with Myanmar. URL: https://www.mea.gov.in/Portal/ForeignRelation/India-Myanmar_Relations.pdf

12. Ministry of Foreign Affairs, Government of the Union of Myanmar: Myanmar's Foreign Policy. URL: http://www.mofa.gov.mm/?page_id=32

13. Myint-U, Thant (2011): Where China Meets India: Burma and the New Crossroads of Asia. London: Faber and Faber Limited.

14. Myoe, Maung Aung (2016): Myanmar's Foreign Policy under the USDP Government: Continuities and Changes. Journal of Current Southeast Asian Affairs, 35 (1): 123-150. URL: http://journals.sub.unihamburg.de/giga/jsaa/article/view/935/942

15. Passi, Ritika and Bhatnagar, Aryaman (2016): Introduction. In Bhatnagar, Aryaman and Passi, Ritika (eds.), Neighbourhood First: Navigating Ties Under Modi, GP-ORF Series (Global Policy-Observer Research Foundation Series). New Delhi: Wiley-Blackwell Publishers. URL: http://www.orfonline.org/wpcontent/uploads/2016/03/GP-ORF_Indias-Neighbourhood1.pdf

16. Pedersen, Morten (2014): Myanmar's Foreign Policy in Transition. In NBR Special Report \#45, Myanmar's Growing Regional Role. Seattle, Washington: The National Bureau of Asian Research.

17. Pulipaka, Sanjay (2014): India-Myanmar Economic Relations. In Bhatia, Rajiv K., Sakhuja, Vijay and Ranjan, Vikash (eds.) Change in Myanmar. New Delhi: Shipra Publications.

18. Ranjan, Vikash (2014): Myanmar in Transition. In Bhatia, Rajiv K., Sakhuja, Vijay and Ranjan, Vikash (eds.) Change in Myanmar. New Delhi: Shipra Publications. 
19. Sein, Chaw Chaw (2014): Political Relations Between Myanmar and India. In Bhatia, Rajiv K., Sakhuja, Vijay and Ranjan, Vikash (eds.) Change in Myanmar. New Delhi: Shipra Publications.

20. Sharma, Richa (2016): India-Myanmar-Thailand Trilateral Highway Agreement Soon. The New Indian Express, New Delhi, 22 May 2016. URL: http://www.newindianexpress.com/nation/India-Myanmar-Thailandtrilateral-highway-agreement-soon/2016/05/22/article3445994.ece

21. Singh, Udai Bhanu (2014): Reform Process: Achievements and the Way Forward. In Bhatia, Rajiv K., Sakhuja, Vijay and Ranjan, Vikash (eds.) Change in Myanmar. New Delhi: Shipra Publications.

22. Steinberg, David I. (1982): Burma: A Socialist Nation of Southeast Asia. Boulder, Colorado: Westview Press.

23. Trivedi, Sonu (2014): India-Myanmar: Rebuilding Synergies and Strengthening Partnership. In Bhatia, Rajiv K., Sakhuja, Vijay and Ranjan, Vikash (eds.) Change in Myanmar. New Delhi: Shipra Publications.

24. Verbruggen, Yola (2016): NLD to Look West, but not Ignore its Tough Neighbours. Myanmar Times, 22 April 2016, URL: http://www.mmtimes.com/index.php/national-news/19911-nld-to-look-west-but-not-ignore-itstough-neighbours.html

25. Yhome, K. (2014): Recent Trends and Developments on Connectivity Between India and Myamar: A Borderland Perspective. In Bhatia, Rajiv K., Sakhuja, Vijay and Ranjan, Vikash (eds.) Change in Myanmar. New Delhi: Shipra Publications.

26. Yhome, K. (2016): Modi's Act East Begins in Myanmar. In Bhatnagar, Aryaman and Passi, Ritika (eds.), Neighbourhood First: Navigating Ties Under Modi, GP-ORF Series (Global Policy-Observer Research Foundation Series). New Delhi: Wiley-Blackwell Publishers. URL: http://www.orfonline.org/wpcontent/uploads/2016/03/GP-ORF_Indias-Neighbourhood1.pdf

27. Zhu, Li (2015): Myanmar's Foreign Policy and Multilateral Relations in the Democracy Process. In Wang, R., and Zhu, C. (eds.) Annual Report on the Development of International Relations in the Indian Ocean Region (2014), Current Chinese Economic Report Series. URL: http://www.cnriio.com/uploadfile/2015/1116/20151116061101115.pdf 